\title{
The Kindest Cut: Christ's Circumcision and the Signs of Early Christian Identity*
}

\author{
ANDREW S. JACOBS
}

\section{Introduction}

In the early second century, the Roman historian Suetonius described an incident from decades earlier under the revenue-hungry Emperor Domitian:

Besides the other [taxes], the Jewish tax (Iudaïcus fiscus) was pursued with especial vigor: for which those persons were turned over (deferebantur $)^{1}$ who either lived a Jewish life undeclared or who, lying about their origins, had not paid the levy imposed on their people (genti). I recall being present, as a teenager, when an old man, of ninety years, was inspected by a procurator (and a crowded court!) to see whether he was circumcised. ${ }^{2}$

* This essay was originally presented at McMaster University in May 2005; I thank all present for their comments and suggestions. Variant portions of this essay were also presented to the Culture and Religion of the Ancient Mediterranean Colloquium at Brown University, the Center for Late Ancient Studies at Duke University, and the Institute for Signifying Scriptures at Claremont Graduate University. I thank all of these institutions for their invitations and encouragement of my work. - The following abbreviations are used for critical editions of ancient texts, followed by volume and page numbers: $\mathrm{CCL}=$ Corpus Christianorum, series Latina (Turnhout: Brepols, 1954-); CSEL = Corpus Scriptorum Ecclesiasticorum Latinorum (Vienna: Akademie Verlag, etc., 1866-); GCS = Die Griechischen christlichen Schriftsteller (Leipzig: J. C. Hinrichs, etc., 1899-); PG = Patrologia Graeca, ed. J.-P. Migne (Paris: Migne, 185766); SC = Sources chrétiennes (Paris: Cerf, 1943-).

1 The verb either indicates prosecution (being "turned over" to the courts) or, more likely, "snitching" (delatio), an interesting glimpse into the dynamics of "multicultural" life in the ancient city.

2 Suetonius, Vita de Caesarum: Domitianus 12.2, text and translation from Suetonius: Lives of the Caesars, Loeb Classical Library, ed. and tr. J. C. Rolfe, 2 vols. (Cambridge: Harvard University Press, 1950-51), 2:364-66. On this incident, see Martin Goodman, "Nerva, the fiscus iudaicus, and Jewish Identity," Journal of Roman Studies 79 (1989): 40-44; Shaye J. D. Cohen, The Beginnings of Jewishness: Boundaries, Varieties, Uncertainties, Hellenistic Culture and Society 31 (Berkeley: University of California Press, 1999), 42-43. 
This brief, brutal scene condenses for Suetonius' readers the complex role of the Jewish covenant in the Roman diaspora: a physical sign of distinction and strangeness that functioned as a legible mark of provincial identity in the fluid cultural economy of the Roman Empire. ${ }^{3}$ Rome did not pursue an imperial logic of homogeneity - like Alexander the Great's ideal of Hellenism ${ }^{4}$ - but instead created an empire that existed precisely to maintain and constrain the observable difference of its subjects. The Jews' own sense of cohesive identity, the covenant, ${ }^{5}$ was registered in visible shorthand through circumcision, ${ }^{6}$ allowing Roman authorities to incorporate Jewish "otherness" metaphorically and literally into an economy of difference.

For this reason we can perhaps understand the tremendous anxiety generated by this doubled sign among early Christians: Paul's intense and repetitive resistance to gentile circumcision might signal the apocalyptic apostle's desire to resist the cultural economy of Empire promulgated by Rome. When later Christians followed Paul's lead (as they understood it), disparaging "circumcision" as a metonym for the rejected covenant of the Jews, it may be that they, too, were seeking to

${ }^{3}$ On the various cultural perceptions of Jewish circumcision in the early empire, see Pierre Cordier, "Les romains et la circoncision," Revue des Études Juives 160 (2001): 337-55 and Ra'anan Abusch, "Circumcision and Castration under Roman Law in the Early Empire," in The Covenant of Circumcision: New Perspective on an Ancient Jewish Rite, Brandeis Series on Jewish Women, ed. Elizabeth Wyner Mark (Hanover and London: Brandeis University Press, 2003), 75-86. On circumcision and late ancient rhetoric of the Roman (male) body, see Gillian Clark, "In the Foreskin of Your Flesh': The Pure Male Body in Late Antiquity," in Roman Bodies: Antiquity to the Eighteenth Century, ed. Andrew Hopkins and Maria Wyke (London: The British School at Rome, 2005), 43-53.

${ }^{4}$ I do not suggest that Hellenism truly created a "universal" Greek culture in antiquity, but rather that its claim to do so was central to the imperial rhetoric of Alexander and the Greek Kingdoms. The cultural legacy of "Hellenism" was much more fluid, as has been charted by Glen W. Bowersock, Hellenism in Late Antiquity, The Jerome Lectures 18 (Ann Arbor: University of Michigan Press, 1990).

5 On a sense of covenant as a shared component of Jewish identity in late antiquity, see the seminal work of E. P. Sanders, Paul and Palestinian Judaism: A Comparison of Patters of Religion (Philadelphia: Fortress, 1977) on "covenantal nomism" (recently reconsidered and, to some extent, critiqued in Justification and Variegated Nomism: A Fresh Appraisal of Paul and Second Temple Judaism, volume I: The Complexities of Second Temple Judaism, ed. D. A. Carson, Peter T. O'Brien, and Mark A. Seifrid [Grand Rapids: Baker Academic, 2001]). See also Seth Schwartz, Imperialism and Jewish Society, 200 B. C. E. to 640 C.E., Jews, Christians, and Muslims from the Ancient to the Modern World (Princeton: Princeton University Press, 2001), 49-97.

${ }^{6}$ Of course, Cohen, Beginnings of Jewishness, 39-48, rightly points out that only in very particular situations was circumcision an especially singular or even "visible" sign of Jewish identity (indeed, the Suetonius incident points out that it was not a routinely visible sign). My point here is the incorporation of this sign ideologically into the Roman cultural economy. 
create a new space for their own religious community outside the cultural logic of Rome. At the same time, however, Christians employed the sign of the Jewish covenant in a manner that mimicked Roman imperial politics, creating out of it a legible sign of difference that could then be absorbed into a dominant mode of identity.

Christians accomplished this feat through a unique expression of that sign: the circumcision of Christ. Already in the first century Christians contemplated the sign of the old covenant on the body of their new savior. We read in the Gospel of Luke, amid a series of scenes solidly fixed in the movement's Jewish origins: "and then the eight days were fulfilled to circumcise him, and he was called by his name, Jesus, which he was called by the angel before he was conceived in the womb" (Luke 2:21). ${ }^{7}$ Throughout late antiquity, and well into the Middle Ages, Christians contemplated Jesus' circumcision, finding facets of their own religious identity reflected in this Jewish mark on the Christian God. ${ }^{8}$

I propose that the incorporation of this paradigmatically Jewish covenant sign on the body of their savior enabled Christians to introduce a sly note of contradiction, paradox, and hybridity into their religious

${ }^{7}$ Although the grammar of the Greek is vague at this point - "circumcise" is an inflected infinitive ( $\tau$ ov $\pi \varepsilon \rho \imath \tau \varepsilon \mu \varepsilon \tilde{\mathrm{i}} v)$, so that there is no finite action described - this verse was universally read (as far as I have found) in antiquity as evidence that Jesus had, in fact, been circumcised. Those "heretics" (from an orthodox Christian standpoint) who denied the circumcision also removed this verse from their gospels, such as Marcion and the later "Julianists" or Aphthartodocetists (see below).

${ }^{8}$ Medieval devotion, focusing especially on the theologically creative (yet controversial) relic of the "holy foreskin," moved in slightly different, equally arresting directions. For a brief but provocative overview, see Marc Shell, "The Holy Foreskin; or, Money, Relics, and Judeo-Christianity," in Jews and Other Differences: The New Jewish Cultural Studies, ed. Jonathan Boyarin and Daniel Boyarin (Minneapolis: University of Minnesota Press, 1997), 345-59. On relics of the holy foreskin in medieval France, see Amy G. Remensnyder, Remembering Kings Past: Monastic Foundation Legends in Medieval Southern France (Ithaca: Cornell University Press, 1995), 172-81. On artistic representations of Christ's maleness, see Leo Steinberg, The Sexuality of Christ in Renaissance Art and Modern Oblivion (New York: Pantheon, 1983), 50-71; Carolyn Walker Bynum, "The Body of Christ in the Later Middle Ages: A Reply to Leo Steinberg," in Fragmentation and Redemption: Essays on Gender and the Human Body in Medieval Religion (New York: Zone Books, 1991), 86-87; and, more recently, Henry Abramson and Carrie Hannon, "Debating the Ambiguous Wound: Circumcision in Medieval Art," in Mark, Covenant of Circumcision, 98-113. The foreskin of Christ figures prominently in the meditative works of fourteenth-century female mystics Agnes Blannbekin (d. 1315) and Catherine of Siena (d. 1380): see the discussion of Caroline Walker Bynum, "The Female Body and Religious Practice in the Later Middle Ages," in Fragmentation and Redemption, 185-86. The potentially salvific properties of Christ's foreskin (and, especially, the blood of his circumcision) do receive brief mention in a letter of Severus of Antioch (d. 538) to a certain Caesaria: see Severus, Epistle 97, text in $A$ Collection of Letters of Severus of Antioch, ed. E. W. Brooks, Patrologia Orientalis 14.1 (Paris: Firmin-Didot, 1920), cols. 194/364-199/369. 
formation. ${ }^{9}$ As they rejected the Jewish covenant, Christians re-appropriated and internalized its mark as a means of crafting a triumphant religious identity that resisted fixed boundaries. In this essay I touch on three areas in which Jesus' circumcision informs early Christian discourses of identity and difference. I begin by discussing how some early Christians dialogically read Christ's circumcision as proof for the rejection of Judaism and its failed covenant. Next, I trace some ways in which the strangely internalized otherness of Christ's circumcision articulated the paradoxes of early Christian heresiology. Finally, I conclude with an examination of one "Church Father's" convoluted use of the circumcision of Christ to define both "true" Judaism and "orthodox" Christianity in his refutation of ancient "Jewish-Christians." In all three areas, we can see how Christians envisioned through this mark of the Jews' covenant not firm boundaries and finite borders, but rather hybridity and the triumphant rejection and internalization of "others."

\section{Judaism}

The Gospel of Luke is our earliest reference to Christ's circumcision, located, as I have said, in a series of accounts (concerning John the Baptist and Jesus) embedding the "holy family" squarely in the ritual and covenantal practices of first-century Judaism. ${ }^{10} \mathrm{I}$ think it is likely that Luke, traditionally viewed as the "gospel for the gentiles," 11 is en-

${ }^{9}$ My conception of identity-formation as a process of abjection and hybridization, in contradistinction to a socioanthropological theory of "boundary-formation," is influenced by psychoanalytic and postcolonial analyses: see, among others, the discussions of Julia Kristeva, Powers of Horror: An Essay on Abjection, tr. Leon S. Roudiez (New York: Columbia University Press, 1982); Homi K. Bhabha, The Location of Culture (London: Routledge, 1994); Robert J. C. Young, Colonial Desire: Hybridity in Theory, Culture, Race (London: Routledge, 1995); and Anne McClintock, Imperial Leather: Race, Gender, and Sexuality in the Colonial Context (London: Routledge, 1995).

${ }^{10}$ The infancy of John the Baptist begins in the Temple at Luke 1:5-80 (the Annunciation is interwoven at Luke 1:26-38), with John's circumcision (in language almost identical to Luke 2:21) at Luke 1:59. In a chiasmic structure, Jesus' circumcision is then followed by scenes of Jesus and his family at the Temple in infancy (commonly known as the "presentation") and in adolescence: Luke 2:22-52.

11 On Luke as the "gentiles' gospel," see Luke Timothy Johnson, "Luke-Acts, Book of," Anchor Bible Dictionary, ed. David Noel Freedman (New York: Doubleday, 1992), 4:403-20 at, for instance, 405: "[Luke's readers] were almost certainly gentile; indeed, a great deal of Luke-Acts makes little sense if they were not gentile believers." But see Jacob Jervell, "The Circumcised Messiah," tr. Roy A. Harrisville in The Unknown Paul (Minneapolis: Augsburg Press, 1984), 138-45 and 183-85 (notes), who argues for a "Jewish Christian." Jervell's argument is placed in historiographic context by Joseph 
gaging in a sort of clever mimicry of the place of Jews in the cultural economy of Rome. ${ }^{12}$ On the one hand, the gospel makes an overt (even apologetic) case for the plausibility and suitability of this new movement in its Roman context, and so adopts signs recognizable to the imperial system; ${ }^{13}$ on the other hand, Christ's circumcision also covertly signals to its readers the "past-tenseness" of the Jewish Temple and covenant, and therefore its obsolescence.

Later interpreters of Jesus' circumcision also played this double game: seizing upon the circumcision of Christ in order to speak authoritatively about Judaism, then turning around and dejudaizing that moment to the point at which this sign of Jewish covenant actually speaks against Jews and Judaism. ${ }^{14}$ Justin Martyr's second-century Dialogue with Trypho the Jew purports to be a record of a debate between Justin the Christian and a diaspora Jew that took place some years earlier. ${ }^{15}$ At its core, the Dialogue is a debate over the person of Jesus and the definition of messiahship; ${ }^{16}$ it is also a thoroughly anti-Jewish text, conveying in dialogue

B. Tyson, Luke, Judaism, and the Scholars: Critical Approaches to Luke-Acts (Columbia: University of South Carolina Press, 1999), 91-109.

12 On "mimicry" (a concept derived from the postcolonial studies of Bhabha) in earliest Christian texts, see Christopher A. Frilingos, Spectacles of Empire: Monsters, Martyrs, and the Book of Revelation, Divinations (Philadelphia: University of Pennsylvania Press, 2004), 10-11 and passim on the transvaluation of Roman moral economies in the Apocalypse of John.

13 New Testament critics have long focused on Luke's "apologetic" or "accommodationist" agenda vis-à-vis the Roman Empire. See P. W. Walaskay, "And So We Came to Rome": The Political Perspective of St Luke, Society for New Testament Studies Monograph Series 49 (Cambridge: Cambridge University Press, 1983), on Luke's specifically imperial sympathies; more generally Gregory Sterling, Historiography and SelfDefinition: Josephos, Luke-Acts, and Apologetic Historiography, Novum Testamentum Supplement 64 (Leiden: Brill, 1992) and Daniel Marguerat, "Luc-Actes entre Jérusalem et Rome: Un procédé lucanien de double signification," New Testament Studies 45 (1999): 70-87.

${ }^{14}$ For a much expanded discussion of Jesus' circumcision in early Christian dialogue texts, see my "Dialogical Differences: (De-)Judaizing Jesus' Circumcision," Journal of Early Christian Studies 15 (2007): 291-335.

${ }^{15}$ For scholarship on the Dialogue, see the overview of Timothy J. Horner, "Listening to Trypho": Justin Martyr's Dialogue Reconsidered, Contributions to Biblical Exegesis and Theology 28 (Leuven: Peeters, 2001), 5-32. Scholars usually date the Dialogue to near the end of Justin's life (perhaps around 155), based on his reference to his First Apology at Dialogus cum Tryphone 120.6; the setting of the Dialogue is usually placed somewhat earlier, as there seems to be a reference to the Bar Kokhba revolt as a recent event (see Horner, Listening to Trypho, 7). Horner makes the argument that the Dialogue contains, as its core, an earlier, mostly faithful record of a real discussion between Justin and Trypho (which Horner calls "The Trypho Text"). While I find Horner's argument interesting, it is difficult to read past the highly literary quality of the "final" text.

${ }^{16}$ As Horner rightly points out: Listening to Trypho, 91. 
form the invalidity of the Jewish covenant and the new salvation brought to gentiles. ${ }^{17}$

Partway through the Dialogue, Justin's interlocutor Trypho broaches Christ's circumcision in order to suggest that Jesus earned his messianic stripes precisely by adhering so faithfully to covenantal Law. When Justin resists this notion of Jesus as a faithful Jew, Trypho complains: "But you have confessed to us (su gar homologesas hèmin) both that he was circumcised and that he kept all of the legal precepts (ta nomima) ordained through Moses!"'18 Justin's response somewhat artlessly attempts to turn Christ's admitted observance of Jewish Law-particularly circumcision-into a sign of something else:

And I replied: "I have confessed it, and I do confess: but I confessed that he underwent all of these things not as if he were made righteous (dikaioumenon) through them, but bringing to fulfillment (apartizonta) the dispensation that his Father - creator of all things, Lord, and God - wished. For likewise I confess that he underwent fatal crucifixion and that he became a human being and that he suffered as many things as those members of your people arranged for him." 19

Christ suffered circumcision as he did "many things" at the hands of the Jews, in order to redeem all of humankind. Contrary to appearances, Christ's submission to the Law spells the end of covenant righteousness, establishing a new boundary between Jew and Christian.

Justin can then go on to underscore the emptiness of the Jewish covenant. ${ }^{20}$ After leading Trypho to concede that the old covenant was established merely to constrain the hardened hearts of the Jews, and that God always promised a "new covenant," ${ }^{21}$ Justin concludes: “'And so!' I said. 'God established that there would be another covenant, not like that constitution (dietage $\overline{\text { ) }}$ of yours, but he said that it would be constituted for them without fear and trembling and lightning-flashes." 22 Jus-

17 Tessa Rajak, "Talking at Trypho: Christian Apologetic as Anti-Judaism in Justin's Dialogue with Trypho the Jew," in The Jewish Dialogue with Greece and Rome: Studies in Cultural and Social Interaction, Arbeiten zur Geschichte des antiken Judentums und des Christentums 48 (Leiden: Brill, 2001), 511-33.

18 Justin Martyr, Dialogus cum Tryphone 67.5. Text in Iustini Martyris Dialogus cum Tryphone, Patristische Texte und Studien 47, ed. Miroslav Marcovich (Berlin: Walter de Gruyter, 1997), 185. There is no prior point in the Dialogue in which Justin does, in fact, "confess" this to Trypho.

${ }^{19}$ Justin Martyr, Dialogus cum Tryphone 67.6 (Marcovich, Iustini Martyris, 185-86).

${ }^{20}$ See, for instance, Justin Martyr, Dialogus cum Tryphone 46-47 (Marcovich, Iustini Martyris, 144-48).

21 On Trypho's "rhetorical concessions," which Horner argues are deliberate and not a sign of Trypho's argumentative weakness, see Listening to Trypho, 156.

22 Justin Martyr, Dialogus cum Tryphone 67.10 (Marcovich, Iustini Martyris, 186). 
tin moves, in a few lines, from "confessing" that Jesus received the mark of the Jewish covenant ${ }^{23}$ to asserting that all of God's actions, including this circumcision, demonstrate the inefficacy of the old covenant and the superiority of the new one. Justin's argument allows him to internalize with authority the voice of Jewish critique (and even reproduce that Jewish voice in literary form) and then turn around and deploy this authoritative voice against Judaism. Yet for Justin to accomplish this feat, that Jewish voice must remain audible - Trypho is never silenced, nor even converted by the end of the Dialogue. Christ's circumcision, while ostensibly serving some supersessionary agenda of Justin's, also signifies an unresolved dialogic tension that calls Justin's religious boundaries into question. ${ }^{24}$

In the next century, the Christian philosopher and exegete Origen discussed Jesus' circumcision in his own apologetic work, the Contra Celsum. Origen had been asked by his patron Ambrose to refute an anti-Christian treatise of Celsus written some sixty years prior. ${ }^{25} \mathrm{Com}$ posed as an interlinear response to Celsus, Origen's work is a defense of Christianity to its pagan despisers and a sophisticated re-appropriation of the Jewish origins of Christianity. As in Justin's text, the Jewish voice is carefully integrated into Origen's defense and definition of Christianity. ${ }^{26}$ This interplay of voices creates a tangled interpenetration of Christian "self" and Jewish "other" that also valorizes the Jewish sign of covenant and uses it to argue against Judaism.

23 A mark derided elsewhere in the Dialogue: see, for instance, Justin Martyr, Dialogus cum Tryphone 16 (Marcovich, Iustini Martyris, 96-97).

${ }^{24}$ It is worth noting, in this connection, Justin Martyr, Dialogus cum Tryphone 47 (Marcovich, Iustini Martyris, 146-48), in which Justin discusses believing Christians who observe the Jewish Law, a practice accepted (with limits) by Justin, but sharply condemned by later Christians (see below on Epiphanius).

${ }^{25}$ Joseph W. Trigg, Origen: The Bible and Philosophy in the Third-Century Church (Atlanta: John Knox Press, 1983), 214-39; Robert Wilken, The Christians as the Romans Saw Them (New Haven: Yale University Press, 1984), 94-125; and, more recently, Michael Frede, "Origen's Treatise Against Celsus," in Apologetics in the Roman Empire, ed. M. Edwards, M. Goodman, and S. Price (Oxford: Oxford University Press, 1999), 131-55. On the philosophical context, see Silke-Petra Bergjan, "Celsus the Epicurean? The Interpretation of an Argument in Origen, Contra Celsum," Harvard Theological Review 94 (2001): 181-206.

${ }^{26}$ The integration of the "Jewish voice" is accomplished at several levels. First, by Celsus' introduction of and Origen's response to a prosopopoetic first-century Jew as a mouthpiece for criticisms of Jesus: Contra Celsum 1.28, 32-44, 56-71, and 2.1, 3-79 (SC 132:150-52, 162-92, 228-74, 276-80, 268-476). Second, by Origen's own display (here, as throughout his oeuvre) of "firsthand" knowledge of Jewish language and culture, on which see my discussion and references in Remains of the Jews: The Holy Land and Christian Empire in Late Antiquity, Divinations (Stanford: Stanford University Press, 2004), 60-67, esp. 61-62. 
Celsus had argued that there was nothing special about Judaism, and it was therefore foolish and even treasonous for Hellenes to abandon their ancestral traditions in order to worship a crucified Jew. ${ }^{27}$ To demonstrate the superiority of Christianity, Origen chooses first to prove the superiority of Judaism, "which has a certain greater wisdom not only than that of hoi polloi, but also of those who bear the semblance of philosophers." 28 After defending the uniqueness of Jewish monotheism, ${ }^{29}$ Origen turns to circumcision.

Origen first asserts that Jewish circumcision, because of its divine warrant, is distinct from the circumcision of Near Eastern pagans. ${ }^{30}$ After praising the Jewish rite, Origen introduces a strange note of disrepute "proven" by Christ's own circumcision. Origen wonders if it was "on account of some angel hostile (polemion) to the Jewish people that this is even performed, who was able to injure those of them who were not circumcised, but was weakened against the circumcised." ${ }^{31} \mathrm{He}$ bases this theory on the enigmatic passage in Exodus 4, where Zipporah's emergency roadside circumcision of her son somehow fends off Yahweh's murderous attack on Moses. ${ }^{32}$ Like many ancient readers of this

27 Origen, Contra Celsum 5.41 (SC 147:120-22), in which Origen cites Celsus as saying, "Now if, following these things, the Jews should cloak themselves in their own law, this is not to their discredit, but rather to those who abandon their own [ways] and make themselves over into Jews." The rest of this section then details the banality of the Jews' religion.

28 Origen, Contra Celsum 5.43 (SC 147:126). On Origen's longstanding argument on the chronological and ontological priority of "Hebrew" wisdom over Greek philosophy, see my discussion and references in "Solomon's Salacious Song': Foucault's Author Function and the Early Christian Interpretation of the Canticum Canticorum," Medieval Encounters 4 (1998): 1-23.

${ }^{29}$ Origen, Contra Celsum 5.45 (SC 147:128-32).

${ }^{30}$ Origen, Contra Celsum 5.47 (SC 147:134): "The reason for the Jews' circumcision is not the same as the reason for the Egyptians' or Colchians' circumcision." Yet Origen also criticizes the Jews for distinguishing their circumcision from that of the "Ishmaelites," which is also derived from the example of Abraham: Contra Celsum 5.48 (SC 147:48): "Even if the Jews boast of circumcision, they will distinguish it not only from the circumcision of the Colchians and Egyptians, but even from that of the Ishmaelite Arabs, even though Ishmael was born of their own forefather Abraham."

31 Origen, Contra Celsum 5.48 (SC 147:138).

32 This incident, of course, continues to arouse exegetical and scholarly curiosity: see the multifarious approaches of William H. Propp, "That Bloody Bridegroom (Exodus IV 24-6)," Vetus Testamentum 4 (1993): 495-523; Seth D. Kunin, "The Bridegroom of Blood: A Structuralist Analysis," Journal for the Study of the Old Testament 70 (1996): 3-16; and Bonna Devora Haberman, "Foreskin Sacrifice: Zipporah's Ritual and the Bloody Bridegroom," in Mark, Covenant of Circumcision, 18-29. See now also my "Blood Will Out: Jesus' Circumcision and Early Christian Readings of Exodus 4:24-26," Henoch 30 (2008): 89-110. 
curious tale, Origen understood the agent of death as the Lord's "angel," from which he concludes:

Now I think this angel had power against those who were not circumcised from the people and generally against all those who worshipped the Creator alone (pantōn tōn sebontōn monon ton dēmiourgon), and he was powerful as long as Jesus had not taken on a body. But when he did take it on, and his body was circumcised, all [the angel's] power against those who were [not] circumcised in this piety was toppled: by his ineffable divinity Jesus toppled him (i. e., the angel). Therefore it is forbidden to his disciples to be circumcised and it is said to them: "For if you are circumcised, Christ is of no benefit to you" (Gal 5:2). ${ }^{33}$

The rite of circumcision, according to Origen, affirms the superiority of the Jews: after all, the "angelic enemy" has singled out the Jews because of their correct worship of the "Creator alone," possibly because he already held sway over the idolatrous pagans. ${ }^{34}$ Yet the mark of the Jewish covenant is also revealed to be, at root, merely a prophylactic talisman rendered moot by Jesus' incarnation. Christ's circumcision, therefore, reveals the hidden truth of Jewish covenant practice: even as it is "superior" to gentile idolatry, it is but a stopgap ultimately eradicated by the new covenant of salvation. The same ritual gesture of Jesus, therefore, can affirm Jewish circumcision and the Pauline injunction against it in Galatians.

Such a double-voiced reading of the Jewish mark on Christ's body appears in later interpreters of the circumcision of Christ. Ambrose of Milan, in his fourth-century Commentary on Luke, interprets Jesus' circumcision as a gesture to bring salvation to the Jews: "He was born under the Law (factus est enim sub lege; cf. Gal 4:4) so that he might win those (lucrifaceret) who were under the Law." 35 Later, in commenting on Jesus' baptism, Ambrose reiterates this point, with an important

33 Origen, Contra Celsum 5.48 (SC 147:138-40).

${ }^{34}$ A different reading of this passage - which I find less tenable given Origen's description of the angel as "hostile" - might view the angel as a covenant enforcer punishing Jews on the Lord's behalf. On early Christian conflation of angels and idolatry, see Annette Yoshiko Reed, "The Trickery of the Fallen Angels and the Demonic Mimesis of the Divine: Aetiology, Demonology, and Polemics in the Writings of Justin Martyr," Journal of Early Christian Studies 12 (2004): 141-71. On Origen and angels, see also the illuminating discussion of Ellen Muehlberger, "Origen and Jerome on Accusations of Jewish Angel Worship," a paper delivered at the 2006 Society of Biblical Literature conference.

${ }^{35}$ Ambrose, Expositio evangeli secundam Lucam 2.55 (CCL 14:54). On Ambrose's exegetical work in the context of his episcopal career, see Boniface Ramsey, Ambrose, The Early Church Fathers (London: Routledge, 1997), 56-60, with a translation of the prologue from the Commentary on Luke,161-65. 
nuance: "The Lord came to the font; now all these things were done for your sake. For those who are under the Law, as if he himself were under the Law, although he is not under the Law (quasi sub lege esset cum ipse sub lege non esset), he was circumcised, so that he might acquire those who are under the Law." 36 Christ's circumcision was for the Jews, yet it was not itself a Jewish circumcision: just as a sinless Christ had no particular need of baptism, so the Son of God, who was not really bound by the Law, underwent superfluous circumcision.

Cyril of Alexandria embellishes this interpretation in the next century. In his own Commentary on Luke, ${ }^{37}$ Cyril points to the positive outreach effected by Jesus' circumcision:

$\mathrm{He}$ is circumcised on the eighth day along with Jews (meta Ioudaion), so that he might confirm his kinship (tèn sungeneian). For the messiah [Christ] was expected from the seed of David, and he offered the proof of his kinship. For if even though he was circumcised they said, "We do not know where he comes from" (John 9:29), had he not been circumcised according to the flesh, and kept the Law, their denial would have had just cause (prophasin eulogon). ${ }^{38}$

Of course, we know that the Jews do reject Christ, and now we learn that they did so without "just cause." Perhaps, Cyril suggests, this was the real reason for Christ's circumcision: to unveil the Jews' covenantal hy-

36 Ambrose, Expositio evangeli secundam Lucam 4.6 (CCL 14:107).

37 Although Cyril's Commentary on Luke seems to have become a standard reference for Byzantine Christians, it survives only in fragmentary condition: some Greek homilies, Syriac translations, and fragments preserved in Byzantine catenae ("chains" of biblical commentaries). Much of this material (but not all) was translated in Gospel of Saint Luke by Cyril of Alexandria, tr. R. Payne Smith (1859; repr. New York: Studion Publishers, Inc., 1983). The homilies on Luke 2:21-39 (the circumcision and presentation), numbered as Homilies 3 and 4 of the Commentary on Luke, and as Homily 12 in the homiliae diversae edited by Migne, have been independently transmitted: see the discussion of the Greek catenae in general by Michel Aubineau, "Les 'catenae in Lucam' de J. Reuss et Cyrille d'Alexandrie,” Byzantinische Zeitschrift 80 (1987): 29-47, and on homiliae 3 and 4 particularly on p. 40, as well as the brief notice by Aubineau, "Deux homélies de Cyrille d'Alexandrie de hypapante (BHG 1958w et 1963)?" Analecta Bollandiana 90 (1972): 100. The comments on this part of Luke 2 are not found in the Syriac edition, although J.-M. Sauget, "Nouvelles homélies du Commentaire sur l'Évangile de s. Luc de Cyrille d'Alexandrie dans leur traduction syriaque," in Symposium Syriacum I, Orientalia Christiana Analecta 197 (Rome: Pont. Institutum Orientalium Studiorum, 1974) describes several unedited fragments of these homilies that corroborate fragments of the Greek catenae.

${ }^{38}$ Cyril of Alexandria, Commentarius in Lucam (in catenis) (PG 72:499D-500A). This passage was included in Cardinal Mai's version of Cyril's commentarial passages found in the catenae, but not in the more recent edition of Joseph Reuss, Lukas-Kommentare aus der griechischen Kirche, Texte und Untersuchungen zur Geschichte der altchristlichen Literatur 130 (Berlin: Akademie Verlag, 1984). 
pocrisy. The very Jewishness of Christ's circumcision, affirmed in its goals, is undermined by its true signification: a rebuke of the "circumcised."

Cyril also uses Christ's circumcision to resolve the seeming contradictions of Paul's preaching, in which Christ is said to be born "under the Law" (Galatians 4), but also to command that "circumcision is of no benefit" (Galatians 5). Cyril writes:

We look upon him also today yielding to the laws of Moses, or rather of God the Lawmaker. ... And for what cause, the very wise Paul teaches when he says: "When we were children, we were enslaved to the elements of the universe. But when the time was fulfilled, God sent forth his son, born of a woman, born under the law so that he might redeem those under the law" (Gal 4:3-5). Therefore Christ has bought off (exepriato) from the curses of the law those who are under the law, but truly not those who are still guarding over it. How has he bought them off? He fulfilled it. ${ }^{39}$

First, the "laws of Moses"-the Jewish covenant-are subtly dejudaized as the "laws of God the Lawmaker." Next, Christ's participation in that Law is read through the lens of Pauline "redemption," literally, "buying back." Finally, Cyril introduces Christ as the "fulfillment" of the Law (cf. Matt 5:17), which we now understand as "payment in full." The Law therefore still holds value, emblematized in circumcision, but it is a value that has been "bought out" by Christ's participation in it. Jesus' submission to the Law is, on this reading, at once a validation and an abrogation of that Law; the mark of Jewishness therefore becomes also the mark of anti-Jewishness.

For all of these Christians, even though Christ's participation in the Jewish covenant somehow affirms that covenant, it also radically devalues it. The sign of the Jews becomes, on Christ's body and in Christian hands, the sign of non-Jewish (or even anti-Jewish) Christianity. Yet this triumph over the Jewish covenant remains always incomplete, as circumcision, refracted through Jesus' body, shows the positive distinction of the Jewish covenant as well as the Jews' own inferiority. For this reason, the Jewish "other" retains an ambivalent place in the articulation of the Christian self. The voice of Trypho is preserved by Justin, the "wisdom" of the Jews upheld by Origen, and even Ambrose and Cyril - two bishops notable for their implication in violence against late ancient Jews $^{40}$ - concede that Christ himself participated in Jewish ritual pre-

${ }^{39}$ Cyril of Alexandria, Homilia 3 in Lucam ( = Homiliae 12 diversae) (PG 77: 1041B).

40 Ambrose famously chastised the Emperor Theodosius I for punishing the Christian synagogue-arsonists in Callinicum in 388: see the discussion in Ramsey, Ambrose, 
cisely to make a gesture of "kinship" (fictive though it may have been). Even in Christianity's most "anti-Jewish" moments, this perplexing mark preserves within itself the traces of Jewishness, uneradicated and unresolved.

\section{Heresy}

This Christian recuperation of "otherness" enabled by Christ's circumcision filtered into other early Christian discourses of distinction. In a variety of heresiological writings, the circumcision of Christ continued to inscribe difference while slyly appropriating that difference into a hybrid Christian "self." In a manner quite different from our dejudaizing apologists, some "orthodox" Christians used the circumcision of Christ to argue against "heresies" they found to be overly dejudaizing. Marcion, a wealthy bishop's son, had proclaimed a popular form of Christianity that sought explicitly to divorce the Jewish God, salvation, and Scriptures from Christian community: the God represented by Christ was a "stranger God," totally distinct from the plodding, material God of the Jews. ${ }^{41}$

The second-century North African Tertullian responds to Marcion's followers by recuperating the value of Jewish Law, and not merely as a typological prolegomenon to Christian faith. Tertullian praises the humane practice of routine slave manumission; he admires the restraint of violence promoted by the lex talionis; and he commends the frugal temperament encouraged by the laws of kashrut. ${ }^{42}$ Tertullian aims to demonstrate the continuity between Jewish Law and Christian grace, and

34-35; and the analysis of this incident by Neil McLynn, Ambrose of Milan: Church and Court in a Christian Capital, Transformation of the Classical Heritage 22 (Berkeley: University of California Press, 1994), 298-315 (and cf. the discussion of the inventio at Bologna, 347-49); Cyril presided over (either directly or by refusing to intervene) Alexandrian mob attacks against Jews in 415, discussed by Norman Russell, Cyril of Alexandria, The Early Church Fathers (London: Routledge, 2000), 7-8, and more general discussion of Cyril's attitude toward Jews and Judaism in Robert L. Wilken, Judaism and the Early Christian Mind: A Study of Cyril of Alexandria's Exegesis and Theology (New Haven: Yale University Press, 1971).

41 On Marcion in his historical context, and the context of later historiography, see the essays collected in Marcion und seine kirchengeschichtliche Wirkung, ed. Gerhard May and Katharina Greschat, Texte und Untersuchungen zur Geschichte der altchristlichen Literatur 150 (Berlin: Walter de Gruyter, 2002).

42 Tertullian, Adversus Marcionem 2.17.4-19.4. Text in Tertullian: Adversus Marcionem, 2 vols., Oxford Early Christian Texts, ed. and tr. Ernest Evans (Oxford: Clarendon Press, 1972), here 1:134-40. 
thereby discount the radical disjuncture between "old" and "new" covenants preached by Marcion.

In one section of Tertullian's refutation, the North African draws on Marcion's own redacted gospel, according to which Jesus supposedly descended straight from heaven-no human birth needed-and began preaching in a synagogue in Capernaum. ${ }^{43}$ Tertullian writes:

Watch him come into the synagogue: certainly to the lost sheep of the house of Israel. Watch him offer the bread of his teaching to the Israelites, the first-born favorites (prioribus ... Israëlitis). ... How could he have been admitted into the synagogue - unexpected and unknown - no one knowing for certain his tribe, his people, his house ... Surely they were mindful of the fact that, unless they knew that he was circumcised, he was not to be let into the most sacred places (sancta sanctorum) ${ }^{44}$

According to Tertullian, even Marcion's abbreviated gospel attests to the Jewish origins of Christianity, literally embodied by Christ: in his movements, his activities, on his person through circumcision. Of course, Tertullian does not then proceed to defend the full participation of Christians in Jewish Law. He will, in fact, along with Marcion, understand by Jesus' proclamation, "The Law and the prophets were in effect until John" (Luke 16:16), that "a certain boundary (quendam limitem) has been established between old things and new, where Judaism should stop and Christianity begin." 45 Yet for Tertullian, that "boundary" between Judaism and Christianity need not be as well-defined as it is for Marcion. Christ's circumcision blurs that boundary-line. Indeed, in other contexts, Tertullian even vehemently insists that the "old Law" of the Jews has ceased, to

${ }^{43}$ According to Tertullian, Adversus Marcionem 4.7.1 (Evans, Tertullian, 2:275-76): anno quintodecimo principatus Tiberiani proponit [Marcion] eum descendisse in civitatem Galilaeae Capharnaum, utique de caelo creatoris, in quod de suo [caelo] ante descenderat. Tertullian also cites Marcion's mockery of the "orthodox" nativity of Christ in De carne Christi 2.1 (SC 216:212). Marcion's gospel was purportedly a redacted version of the Gospel of Luke: see Appendix 2, "Marcion's Treatment of the New Testament," in Evans, Tertullian, 2:643-46.

44 Tertullian, Adversus Marcionem 4.7.6-7 (Evans, Tertullian, 2:278). The forcefulness of Tertullian's defense here is made all the more notable, again, by contrast with his treatise Adversus Iudaeos, where his description of Christ as the "mountain" "sine manibus concidentium praecisus" may be a blending of Daniel 2:34 (a "stone cut away without hands") with Colossians 2:11 ("a circumcision performed without hands") that diminishes the significance of Christ's circumcision (Adversus Iudaeos 3.9; text in Q. S. F. Tertulliani Adversus Iudaeos mit Einleitung und kritischem Kommentar, ed. Hermann Tränkle [Wiesbaden: Franz Steiner Verlag, 1964], 8). Interestingly, parts of the Adversus Iudaeos may have been written at the same time as sections of the Adversus Marcionem: see the discussion in Tränkle, Tertulliani, LIII-LIX.

${ }^{45}$ Luke 16:16, cited by Tertullian, Adversus Marcionem 4.33.7-8. (Evans, Tertullian, 2:446). 
make way for the "new law and the spiritual circumcision." 46 We should not dismiss Tertullian's double-sided discourse as simply rhetorical convenience. His simultaneous rejection and reinternalization of Jewishness seem deliberate and judicious. Because Jesus so authoritatively straddles that boundary, Tertullian can assert the theological division between Judaism and Christianity even while asserting an equally sharp division between the "orthodox" and the heretical followers of Marcion. ${ }^{47}$ Tertullian's rhetoric of orthodoxy gains traction from its ability both to reject and absorb the "other," to assert difference and yet internalize that difference into the heart of Christian truth.

We see this desire to recuperate "otherness" through Christ's circumcision also in heresiological contexts that seem to have little to do with Judaizing or dejudaizing. In the late fourth century, Athanasius of Alexandria intervened in a Christological debate in the city of Corinth. Two parties had reached opposite conclusions about Christ's humanity and divinity. One group asserted that God's Word was only loosely united to the person of Christ "by attribution, and not by nature" (thesei kai ou phusei). ${ }^{48}$ Their opponents argued that the union between human and

46 Tertullian, Adversus Iudaeos 3.11 (Tränkle, Tertulliani, 8). On the still vexed question of Tertullian's “anti-Judaism," see Geoffrey D. Dunn, "The Universal Spread of Christianity as a Rhetorical Argument in Tertullian's adversus Iudaeos," Journal of Early Christian Studies 8 (2000): 1-19; idem, "Tertullian and Rebekah: A Re-Reading of an 'Anti-Jewish' Argument in Early Christian Literature," Vigiliae Christianae 52 (1998): 119-45; idem, "Pro temporum condicione: Jews and Christians as God's People in Tertullian's adversus Iudaeos," in Prayer and Spirituality in the Early Church, vol. 2, ed. Pauline Allen et al. (Brisbane: Centre for Early Christian Studies, Australian Catholic University, 1999), 315-41.

47 Tertullian's theological gesture is modeled, perhaps, on the political economy of the Roman Empire, which also relied on porous frontiers. C. R. Whittaker has been at the fore of a historiographic rereading of Roman limites not as "boundaries" but as "frontier zones of interaction": see Frontiers of the Roman Empire: A Social and Economic Study (Baltimore: Johns Hopkins University Press, 1994); and Rome and its Frontiers: The Dynamics of Empire (London: Routledge, 2004).

48 Athanasius, Epistula ad Epictetum 2 apud Epiphanium, Panarion 77.4.4 (GCS 37:419). According to Élie D. Moutsalas, "La lettre d'Athanase d'Alexandrie à Epictète," in Politique et théologie chez Athanase d'Alexandrie, ed. Charles Kannengeisser, Théologie Historique 27 (Paris: Beauchesne, 1974), the letter was written "in 371 or a little earlier" (p. 133). The letter is preserved by Epiphanius in his chapter on the Apollinarians (also called "Dimoirites"); but it was likely written after Athanasius received the minutes of various European synods in the early 360s and does not seem to represent with any recognizable specificity actual positions of Apollinarius of Laodicea. Hans Lietzmann, Apollinaris von Laodicea und seine Schule: Texte und Untersuchungen (Tübingen: J. C. B. Mohr [Paul Siebeck], 1904), 11-12, accepted it as an authentic critique of Apollinarius; and Charles Raven, Apollinarianism: An Essay on the Christology of the Early Church (Cambridge: Cambridge University Press, 1923), 103-10, argued for an early dating of the letter (before 362) and rejected that idea that Athanasius is 
divine natures was so total that Christ's physical body was, in some sense, divinized, that "the Word has been transformed into flesh, bones, hair, sinews, and the whole body."49 Athanasius' rebuttal recuperates elements of both parties' beliefs: the distinction between human and divine natures and the consubstantiality of the Son and the Father. Yet Athanasius was not merely perfecting the recipe of humanity and divinity that would produce a theologically palatable person of Christ; he was crafting a sophisticated method for both rejecting and re-appropriating the theological positions of his theological opponents.

Christ's circumcision, possibly first introduced by the Corinthians themselves, ${ }^{50}$ again serves as the key to this double-sided heresiological discourse. First arguing for the irrefutable humanity of Jesus, Athanasius runs through a litany of Lucan passages proving the reality of Christ's human body:

This is the body circumcised on the eighth day, this body Symeon received in the crook of his arms, that became a child, and grew into his twelfth year, and became thirty years old. For it was not the very nature of the Word which, being altered, was circumcised; for it is unalterable and unchangeable, as the Savior himself says. ${ }^{51}$

The circumcision of Christ - a radical alteration to Jesus' human form shows that his body could not have been divine, for God cannot be changed or altered. Here Athanasius drifts toward the theological position of the "attributionists," who insisted on a clear distinction between

arguing against Apollinarius or his followers at all, preferring instead varied and confused groups of pro-Nicene "docetists." Moutsilas, "Lettre," acknowledges that the argument about Christ's divine body does not "come from Apollinarius," but asserts nonetheless that it emerges from "Apollinarian circles" that likely misinterpreted Apollinarius (pp. 322-25).

${ }^{49}$ Athanasius, Epistula ad Epictetum 2 apud Epiphanium, Panarion 77.4.3, 6.5 (GCS 37:419, 421).

${ }^{50}$ Athanasius seems to cite one of the Corinthian factions as claiming that "that divinity, which was consubstantial with the father, $\pi \varepsilon \rho 1 \varepsilon \tau \mu \eta \vartheta \eta[$ [perietmēthe $]$ and that imperfection came to be out of perfection" (Epistula ad Epictetum 2 apud Epiphanium Panarion 77.4.4 [GCS 37:419]). $\pi \varepsilon \rho 1 \varepsilon \tau \mu \eta \dot{\vartheta \eta ~ c a n ~ h a v e ~ s e v e r a l ~ m e a n i n g s, ~ i n c l u d i n g ~ " w a s ~}$ circumcised." In context, it may simply mean that the divinity "was curtailed" (modern English translators have gone both ways). Compare the Nicene and Post Nicene Fathers translation, which renders this "circumcised" (Athanasius: Select Works and Letters, in Nicene and Post-Nicene Fathers, Second Series, vol. 4, ed. Philip Schaff, [New York: Christian Literature Publishing Co., 1892], 570) with Frank Williams who, in his English translation of Epiphanius' Panarion, translates it as "curtailed" (Frank Williams, The Panarion of Epiphanius of Salamis, vol. 2, Nag Hammadi Studies 36 [Leiden: E. J. Brill, 1987], 570). It is clear that Athanasius, however, understood them to be speaking of Christ's circumcision.

51 Athanasius, Epistula ad Epictetum 5 apud Epiphanium, Panarion 77.7.5 (GCS 37:422), referring to Luke 2:21, 2:28, and 2:40. 
the transcendent Godhead and limited humanity. Yet Athanasius continues directly: "But indeed in the body being circumcised, and being carried around, and eating, and tiring, and affixed to the tree, and suffering, was the impassible and bodiless Word of God." 52 Here, the nub of the "consubstantialist" position is neatly recouped, for all of the "changes" ascribed to the fully human Christ-the first of which is, again, circumcision-only have theological meaning if the Word is fully united with that mutable human.

Athanasius even admits that he is upholding at the same time the contradictory positions of the two Corinthian camps, declaring that "it was a paradox, that he who suffered also did not suffer. ... The bodiless one was in the suffering body, but the body had within it the unsuffering Word." 53 Athanasius is not simply "working out" the complex metaphysics of his incarnational theology, prompted by controversies in Corinth. ${ }^{54}$ Rather, the Alexandrian bishop is exploiting an opportunity to demonstrate the triumph of orthodoxy, ${ }^{55}$ the full and total confession of faith so powerful that it can defeat-and yet absorb-the theological assumptions of its enemies on all sides. Jesus' circumcision, in its unquestionable otherness and necessary Christianness, provides the orthodox an opening through which to master and internalize the theological difference of its opponents. ${ }^{56}$ Even removed from its Jewish context, it

52 Athanasius, Epistula ad Epictetum 5 apud Epiphanium, Panarion 77.7.7 (GCS 37:422-23).

53 Athanasius, Epistula ad Epictetum 6 apud Epiphanium, Panarion 77.8.6-7 (GCS 37:423).

${ }^{54}$ Indeed, he notes at the close of his letter that all of the various disputes in Epictetus' congregations had been settled: "But thanks be to the Lord that, as much as we grieved reading the minutes, so much did we rejoice at their conclusion: for afterwards they left in concord and made peace on the confession of pious and orthodox faith!" (Athanasius, Epistula ad Epictetum 12 apud Epiphanium, Panarion 77.13.45 [GCS 37:427]).

55 Athanasius notes at the outset how surprised he is that such controversies can still arise after Nicaea (Epistula ad Epictetum 1 apud Epiphanium, Panarion 77.3.1 [GCS 37:417]); the closing burst of "joy" at resolution lets us know that such fears are unfounded, that Nicaea does indeed triumph in the end, even without Athanasius' intervention.

56 The circumcision of Christ would continue to irrupt into Christological debates, especially as the metaphysical union of humanity (especially carnality) and divinity came to the fore. It appears in the debates between Nestorius and Cyril of Alexandria in the early fifth century: see Nestorius, Epistula 2 ad Cyrillum 8, text in Acta Conciliorum Oecumenicorum, ed. Eduard Schwartz, vol. 1.1.1 (Berlin: Walter de Gruyter, 1927), 31-32. It arises also in the later "Julianist" or "Aphthartodocetist" controversy in the sixth century: see the reference in note 8 to Severus of Antioch and also Philoxenus of Mabbug, Fragments of the Commentary on Matthew and Luke, ed. J. W. Watt, Corpus Scriptorum Christianorum Orientalium 392-93 (Louvain: Corpus Scriptorum 
emblematizes the absorption and conquest of difference that enables a dominant selfhood.

\section{Jewish-Christianity}

From double-voiced dejudaizing to heresiological paradox, the circumcision of Christ emerged as a dodgy sign of the hybrid logic of Christian difference. I conclude with an early Christian text that synthesizes both the dejudaizing and heresiological uses of Christ's circumcision. Fourthcentury heresiologist Epiphanius of Salamis includes in his compendious "Medicine-Chest Against Heresies" a long chapter against the "Ebionites." 57 Epiphanius found this "heresy," positioning itself "midway" (mesos) between Judaism and Christianity, ${ }^{58}$ especially odious: a "monstrosity with many shapes," 59 claiming both religious traditions yet failing to practice either correctly.

According to Epiphanius, Ebionite insistence on circumcision epitomized their slapdash attempts at synthesized "Jewish-Christianity":60

Christianorum Orientalium, 1978), 392:38-39 (Syriac) and 393:33-34 and discussion in Clemens Leonhard, "Die Beschneidung Christi in der syrischen Schatzhöhle: Beobachtungen zu Datierung und Überlieferung des Werks," in Syriaca II: Beiträge zum 3. deutschen Syrologen-Symposium in Viersehnheiligen 2002, ed. M. Tamcke, Studien zur Orientalischen Kirchengeschichte 33 (Münster: LIT-Verlag, 2004), 11-28. Many thanks to Lucas van Rompay for drawing my attention to these Syriac sources.

57 On the Panarion in general, see Aline Pourkier, L'hérésiologie chez Epiphane de Salamine (Paris: Beauchesne, 1992); Averil Cameron, "How to Read Heresiology," Journal of Medieval and Early Modern Studies 33 (2003): 471-92; and the slender but competent introduction to the translation by Williams, Panarion, 1: ix-xxvii. The chapter against the Ebionites is one of three chapters against so-called (by modern scholars) "Jewish-Christian" heresies: see Glenn Alan Koch, "A Critical Investigation of Epiphanius' Knowledge of the Ebionites: A Translation and Critical Discussion of Panarion 30," Ph. D. diss., University of Pennsylvania, 1976; and Joseph Verheyden, "Epiphanius on the Ebionites," in The Image of the Judaeo-Christians in Ancient Jewish and Christian Literature, ed. Peter J. Tomson and Doris Lambers-Petry, Wissenschaftliche Untersuchungen zum Neuen Testament 158 (Tübingen: Mohr-Siebeck, 2003), 182-208.

58 Epiphanius, Panarion 30.1.4 (GCS 25:333-34).

59 Epiphanius, Panarion 30.1.1 (GCS 25:333).

60 The term "Jewish-Christianity" is, of course, a modern designation for a variety of groups (real or imagined) that somehow blurred the lines between (what we, or they perceived as) Christianity and (what we, or they perceived as) Judaism. See Joan E. Taylor, "The Phenomenon of Early Jewish-Christianity: Reality or Scholarly Construct?" Vigiliae Christianae 44 (1990): 313-34; the comments and references of Stephen Shoemaker, Ancient Traditions of the Virgin Mary's Dormition and Assumption, Oxford Early Christian Studies (Oxford: Oxford University Press, 2002), 212-14, 229 31; and several of the essays in The Ways that Never Parted: Jews and Christians in Late Antiquity and the Early Middle Ages, Texts and Studies in Ancient Judaism 95 (Tübingen: Mohr-Siebeck, 2003). 
They are proud to possess circumcision and even boast that this is the seal and the imprint (sphragida kai charaktera) of the patriarchs and the righteous ones who have conformed to the Law (kata ton nomon pepoliteumenōn), for which they suppose they are equal to them. Yet what's more, they wish to derive proof for this from Christ himself, just like the Cerinthians. ${ }^{61}$ According to their silly reasoning (lērōde logon) they also say, "It is enough for the disciple to be as his master [Matt 10:25]. Christ was circumcised; you be circumcised too!"62

The Ebionites claim Judaism and Christianity at once, the Law of the patriarchs and faith of Christ, sealed and imprinted in their insistence on the validity of circumcision. Yet, according to Epiphanius, their pretensions at fulfilling both religions are a mockery. ${ }^{63}$ After detailing the Ebionites' deficient Christianity - their heretical Christologies, their "corrupt and mutilated" Scriptures, their ignorance of proper ritual ${ }^{64}$ Epiphanius explains their faulty Judaism, as well.

Although the Ebionites think that by circumcising themselves they imitate the "patriarchs and the Law," they in fact follow a lame-brained heretic ${ }^{65}$ : "The misguided Ebionites are very unfortunate to have abandoned the testimonies of the prophets and angels and content themselves with the misguided Ebion-who wants to do what he likes, and

${ }^{61}$ Epiphanius had already ascribed this defense of circumcision as imitatio Christi to Cerinthus (Panarion 28.5.1-3 [GCS 25:317]), taken there to be the "troublemaker" of Acts 21:28 who has Paul arrested for "polluting" the Temple with his uncircumcised companion Titus. But see Charles E. Hill, "Cerinthus, Gnostic or Chiliast? A New Solution to an Old Problem," Journal of Early Christian Studies 8 (2000): 135-72, who posits that Epiphanius' description of Cerinthus as a Judaizer constitutes a (willful or otherwise) misreading of Irenaeus, and concludes that Cerinthus was, in fact, a thoroughly dejudaized Christian predecessor of Marcion. This would mean that the use of Matthew 10:25 and the call to Jesus' example for circumcision were retrojected backwards (two chapters) by Epiphanius, and explains why his serious refutation of the example of Christ's circumcision waits until his chapter against the Ebionites. It also calls into question whether anyone-Cerinthian, Ebionite, or otherwise-ever made such an exegetical argument relating Matthew 10:25 to an account of Jesus' circumcision, or whether it derived entirely from Epiphanius' imagination.

62 Epiphanius, Panarion 30.26.1-2 (GCS 25:368). The reference to the Cerinthians' "silly reasoning" may be a punning allusion to the Jewish-Christians' defective understanding of Christ (the Logos).

${ }^{63}$ Stated succinctly a little later by Jerome, Epistle 112.13.2: quid dicam de Hebionitis, qui Christianos esse se simulant? ... dum volunt et Iudaei esse et Christiani, nec Iudaei sunt nec Christiani (CSEL 55:381-82).

${ }^{64}$ Christology: Panarion 30.3.3-5, 17.5-7, 20.1 (GCS 25:336-37, 356-57, 359); see Koch, "Critical Investigation," 247-54 and 281-94; Scriptures: Panarion 30.13.2, 18.4, 18.7 (GCS 25:349, 357-58); rituals: Panarion 30.32 (GCS 25:376-79).

${ }^{65} \mu \alpha \tau \alpha i ́ \varphi \rho \omega v$, used repeatedly of Ebion and the Ebionites: Panarion 30.26.7, 30.30.1, 30.32.1, 30.34.1 (GCS 25:369, 374, 377, 380). "Lame-brained" is the felicitous translation of Frank Williams (see above, n. 50). 
practice Judaism, even though he is estranged from Jews (apo Ioudaiōn ellotriōmenou)." ${ }^{66}$ Ebion may try to look like a Jew, but he is, in essence, a "stranger" to them. Directly contrary to Ebion, Christ is "not a stranger to the Law" (ou ton nomon allotrion), ${ }^{67}$ and his circumcision highlights, against Ebion, the real nature of this "seal and imprint" among the Jews.

Epiphanius writes that Christ ordained his own circumcision in order to confirm his own command that Abraham and his descendants be circumcised. ${ }^{68}$ The "affirmation" of Christ's circumcision, however, completely reconfigures the Jewish covenant:

The visible circumcision was instituted because of Abraham's doubt. ... [God] laid physical circumcision on him and his [kin] to keep them from forgetting the God of their fathers when enslaved by the idolatrous, unbelieving Egyptians. They would see their circumcision, be reminded and feel ashamed, and not deny him. And until Christ this remained the case, and because of it he too consented to be circumcised. ${ }^{69}$

Through Christ's circumcision, Epiphanius can authoritatively rewrite the Jewish covenant as the mark of ignominy. ${ }^{70}$ The orthodox Christian, who reviles the Jewish religion, can demonstrate superior knowledge of it against the "heretic" who tries to validate its practices. Epiphanius' display of "real" Judaism in refutation of the pseudo-Jewish Ebionites is, in some respects, an ideological tour de force: a demonstration that Christianity can, with ease and agility, control knowledge of that deeply ingrained "other," the Jew. ${ }^{71}$ Yet the "truth" of Judaism must also be

${ }^{66}$ Epiphanius, Panarion 30.20.8 (GCS 25:360-61).

${ }^{67}$ Epiphanius, Panarion 30.27.2 (GCS 25:370). Epiphanius cites Matthew 5:27 here

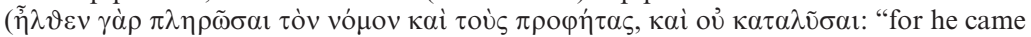
to fulfill the Law and the prophets, not to abolish them"), an exegetical proof-text that - by the fourth century - carried the sense of "fulfillment" as "brought to fullness," understood by anti-Judaizing Christians as abrogation of the Law: see Cyril of Alexandria's comments, above.

${ }^{68}$ Epiphanius, Panarion 30.28.5 (GCS 25:371): "Moreover it was necessary that he who commanded that Abraham should be circumcised ... Christ should confirm this by being circumcised."

69 Epiphanius, Panarion 30.28.6-8 (GCS 25:371-72).

70 The failure to understand the truth about their own Law and prophets characterizes the "heresy" of Judaism, according to Epiphanius: Panarion 8.7.1 (GCS 25:193): "since then they were guided by the type and did not achieve the perfection which has been preached through the Law and the prophets and the others, and every book, they were cast out of the pasture."

${ }^{71}$ See Daniel Boyarin, Border Lines: The Partition of Judaeo-Christianity, Divinations (Philadelphia: University of Pennsylvania Press, 2004), 209, in the context of Jerome's anti-Judaizing heresiology: "the assertion of the existence of a fully separate-from-Christianity 'orthodox' Judaism functioned for Christian orthodoxy as a 
internalized, inscribed as it is on the body of Epiphanius' savior. The appropriation of Judaism that led the Ebionites astray, transforming them into nightmarish, polymorphic "monsters," is therefore ironically and craftily reproduced in Epiphanius' own interpretation of the circumcision of Christ.

For Epiphanius, not only is the semi-Judaism of the Ebionites transformed by Christ's circumcision, but so is all manner of Christian "otherness": Jews and heretics alike are transformed and absorbed into his orthodox triumph. Epiphanius gives four reasons for Jesus' circumcision:

First, to prove that he had actually taken flesh, because of the Manichaeans, and those who say he has (only) appeared in a semblance. Then, to show that the body was not of the same nature as the Godhead, as Apollinarius says, and that he had not brought it down from above, as Valentinus says. And [third] to confirm the fact that the circumcision he had given long ago served legitimately until his advent, and [fourth] to deprive the Jews of an excuse: for, if he had not been circumcised, they could have said, "we could not accept an uncircumcised messiah."72

A panoply of heretics are proleptically chastised and expelled by Christ's circumcision, even as this same sign affirms and reaches out to the Jews. ${ }^{73}$ This rejection of heresy and appropriation of Judaism are, at least, ironic in a tract written against a Judaizing heresy. Yet this is precisely the hybridizing and even contradictory work that the divine circumcision performs in early Christianity: heretics are rejected, even as their "heretical" assertions (Christological divinity and fleshliness) are recuperated; Jews are appeased, even as their continued denial of Christian truth is marked as unjust and inexcusable. Rejection, reconciliation, abrogation, appropriation, all are present in the incongruous sign of the Jewish covenant on the body of the savior who, it was believed, dissolved that covenant. Christ's circumcision, in the agile hands of Epiphanius, provides the opportunity for Christians fully to contemplate their own hybridized nature, the site at which all of their sharply defined boundaries seem to blur into a hazy and incoherent horizon.

Our standard narrative of Christian origins - derived, to a great degree, from the early Christians themselves - is one of forceful differentia-

guarantee of the Christian's own bounded and coherent identity and thus furthered the project of imperial control."

72 Epiphanius, Panarion 30.28.2-4 (GCS 25:371).

73 These two categories of explanation for Christ's circumcision-refutation of Christological heresy and "outreach" to the Jews - are reiterated at Panarion 30.28.9 (GCS 25:372): "to deprive the Jews of their excuse [and] for the refutation of Manichaeans and others." 
tion. ${ }^{74}$ "Neither Jew nor Greek" transmutes into apologetic distinction from Judaism and paganism, and the various anxious literatures of difference - apologies, heresiologies, texts adversus Iudaeos - seem to confirm for us the absolute rejection of "otherness" in the articulation of the Christian self. Yet in the circumcision of Christ, I suggest, we can see beyond this narrative: as Christians disparaged and rejected "the other," they simultaneously inscribed that otherness within. Justin's argument against Jewish Law preserves for posterity the voice of Jewish resistance; Cyril's anti-Jewish messiah preserves on his very body the dashed hope of Jewish rapprochement; even Epiphanius' refutation of hybridizing "Jewish-Christians" creates an orthodox hybridity which can (and must) speak with intimate knowledge the "truth" of Judaism deep inside. Rome transformed the alien mark of the Jewish covenant into a negotiable sign of difference within the permeable frontiers of Empire. For Christians also, we learn, difference and distinction are never absolute but always permeable and negotiable. Even the paradigmatic sign of covenantal otherness, circumcision, functions not as the clear and insistent demarcation between "us" and "them," but rather the more subtle recognition of the ways in which "they" are always and inevitably part of "us," a simultaneous rejection and sly recuperation of "otherness" even at the deepest levels of religious identity, inscribed on and within the body of the founder himself.

${ }^{74}$ See Judith Lieu, "'Impregnable Ramparts and Walls of Iron': Boundary and Identity in Early 'Judaism' and 'Christianity,"' New Testament Studies 48 (2002): 297-313. 